\title{
CONSIDERATIONS ON INFORMAL LEARNING: DIFFERENT CONCEPTS AND THEIR DIMENSIONS
}

\author{
Ramune Bagdonaite-Stelmokiene \\ Vilma Zydziunaite \\ Vytautas Magnus University, Lithuania
}

\begin{abstract}
The definition of "informal learning" is ambiguous and thus distinguished by the diverse interpretations. The article aims to reveal identical learning dimensions (process, activity, context, interactions and outcomes), which set up different concepts of "informal learning". The research question refers to the content of dimensions for distinct concepts of "informal learning". The analysis has disclosed the "informal learning" to be continuum between "self-directed learning", "self-regulated learning", "self-managed learning", "experiential learning", "incidental/accidental learning", "situated learning", "learning through socialization" or "tacit learning". Those diverse types of "informal learning" supplement each other rather than compete against. Learning intention, process and context setting might be manifested in distinct degrees, however, "informal learning" may refer to the construct covering learning forms, activities and acquired learning outcomes supplementing each other.
\end{abstract}

Keywords: comparison, dimension, informal learning, literature review.

\section{Introduction}

Informal learning is perceived as conscious and/or unconscious, casual / random and not intentionally planned and more or less in advance organized action that refers to acquisition of learner's competences (Schugurensky, 2000). This learning form might be applied both at individual and group level, thus referring to diverse social interactions. Yet there are still a lot of misapprehensions referred to identification and definition of informal learning conception. As informal learning owns many different definitions that overlap each other, the important discussion should cover diverse definitions and types of informal learning specifying identical learning dimensions (Carliner, 2013). It is important to research the limits distinguishing diverse conceptions of informal learning.

Some authors identify informal learning as self-directed learning (Livingstone, 2001; Tough, 2002) or experiential learning (Gola, 2009). Schugurensky (2000) provides typology of informal learning based on the two main categories: learning intentionality and conscience. This researcher suggests to distinguish the informal learning into three types: i) self-directed 
Ramune Bagdonaite-Stelmokiene, Vilma Zydziunaite. Considerations on Informal Learning: Different Concepts and their Dimensions

learning, ii) intentional learning and iii) learning through socialization. Gola (2009) and Marsick (2009) describe informal learning by originating it from experiential learning, incidental learning, self-directed learning and tacit learning. Duguit and Schugurensky (2013) point out informal learning to be self-directed: i) intentional and conscious; ii) incidental - unintentional though conscious; and iii) tacit learning - unintentional and unconscious. Pintrich and Zusho (2002), Cunningham (2010), Jossberger (2010) and Morgan (2013) distinguish self-regulated and self-managed types of informal learning. Lave and Wenger (1991), Chaiklin and Lave (1993) mark out situated learning as one more type of informal learning. With the reference to informal learning, the following learning types are closely linked: self-directed learning, self-regulated learning, self-managed learning, experiential learning, incidental / accidental learning, situated learning, and learning through socialization. Thus, the article analyses namely those informal learning types that cover differences and overlaps of definitions.

The conception of informal learning lacks the systemic approach and validation answering the questions why, where, when, how and what is being learnt referring to informal learning (Straka, 2004). Thus, informal learning conceptions may be analysed revealing learning activities, processes, contexts, the places it occurs, interactions being active and outcomes (Marsick, 2009).

Different research outcomes are focused on the general features of informal learning process, whereas concepts in use are not explained precisely. Thus, it is difficult to perceive whether different informal learning concepts are diverse and where this diversity or overlaps occur? Consequently the research question is raised: What is the content of dimensions referring to diverse informal learning concepts?

The aim of the study was to disclosure of identical dimensions that compile diverse informal learning concepts.

\section{The different types of 'informal learning' and their dimensions}

Different authors (Straka, 2004; Marsick, 2009) highlight the lack of distinction of informal learning concepts in regard to the main learning dimensions: how, where, with whom / what and which are being learnt. Thus, the main informal learning types - self-directed learning, self-regulated learning, self-managed learning, experiential learning, incidental / accidental learning, situated learning, learning through socialization - are analysed referring to the main five learning dimensions: process, activity, context, interactions and outcomes (see Table 1). 
Table 1 Informal learning types and their dimensions

\begin{tabular}{|c|c|c|c|c|c|}
\hline \begin{tabular}{|l|l|} 
Informal \\
Learning Type
\end{tabular} & Process & Activities & Context & Interactions & Outcomes \\
\hline $\begin{array}{l}\text { Self-directed } \\
\text { learning } \\
\text { (Schugurensky, } \\
\text { 2000; } \\
\text { Livingstone, } \\
\text { 2001; Lin and } \\
\text { Lee, 2014) }\end{array}$ & $\begin{array}{l}\text { Conscious; } \\
\text { Intentional; } \\
\text { Structured }\end{array}$ & $\begin{array}{l}\text { Action activities: } \\
\text { learning by doing; } \\
\text { Cognitive activities: } \\
\text { self-control, } \\
\text { reflection; } \\
\text { Interaction } \\
\text { activities: } \\
\text { conversations }\end{array}$ & $\begin{array}{l}\text { Diverse, } \\
\text { anticipated } \\
\text { by learner } \\
\text { environment: } \\
\text { daily } \\
\text { environment, } \\
\text { work } \\
\text { environment }\end{array}$ & \begin{tabular}{|l} 
Individual \\
learning \\
(without \\
educator, tutor); \\
Interpersonal \\
interactions: \\
with associates, \\
resource person
\end{tabular} & $\begin{array}{l}\text { Acquired specific, } \\
\text { the most } \\
\text { requested/ lacking } \\
\text { knowledge and } \\
\text { skills necessary } \\
\text { for solving real } \\
\text { world issues; } \\
\text { Personal } \\
\text { development }\end{array}$ \\
\hline $\begin{array}{l}\text { Self-regulated } \\
\text { learning } \\
\text { (Zimmerman, } \\
\text { 1990; Pintrich } \\
\text { and Zusho, } \\
\text { 2002; } \\
\text { Jossberger, } \\
\text { 2010; Morgan, } \\
\text { 2013) } \\
\end{array}$ & $\begin{array}{l}\text { Conscious; } \\
\text { Intentional; } \\
\text { Structured }\end{array}$ & $\begin{array}{l}\text { Action activities; } \\
\text { Cognitive activities: } \\
\text { intentional tasks, } \\
\text { strategies } \\
\text { repertoires, goal } \\
\text { setting, self-control, } \\
\text { motivation }\end{array}$ & $\begin{array}{l}\text { Diverse, } \\
\text { anticipated } \\
\text { by learner } \\
\text { environment }\end{array}$ & $\begin{array}{l}\text { Individual } \\
\text { learning }\end{array}$ & $\begin{array}{l}\text { Obtained } \\
\text { information; } \\
\text { Competence } \\
\text { development; } \\
\text { Learning; Personal } \\
\text { development: self- } \\
\text { improvement, } \\
\text { strengthening own } \\
\text { strong sides }\end{array}$ \\
\hline $\begin{array}{l}\text { Self-managed } \\
\text { learning } \\
\text { (Cunningham, } \\
2010 ; \\
\text { McConnell, } \\
\text { 2013) }\end{array}$ & $\begin{array}{l}\text { Conscious; } \\
\text { Intentional; } \\
\text { Structured }\end{array}$ & $\begin{array}{l}\text { Action activities; } \\
\text { Cognitive activities: } \\
\text { learning activities } \\
\text { construction, self- } \\
\text { control, motivation, } \\
\text { reflection }\end{array}$ & $\begin{array}{l}\text { Diverse, } \\
\text { anticipated } \\
\text { by learner } \\
\text { environment }\end{array}$ & $\begin{array}{l}\text { Individual } \\
\text { learning }\end{array}$ & $\begin{array}{l}\text { Acquired new } \\
\text { knowledge } \\
\text { Learning }\end{array}$ \\
\hline $\begin{array}{l}\text { Situated } \\
\text { learning } \\
\text { (Lave and } \\
\text { Wenger, 1991; } \\
\text { Chaiklin and } \\
\text { Lave, 1993) }\end{array}$ & $\begin{array}{l}\text { Conscious; } \\
\text { Intentional; } \\
\text { Structured; } \\
\text { Social practice }\end{array}$ & $\begin{array}{l}\text { Action activities: } \\
\text { professional and } \\
\text { social practice; } \\
\text { Cognitive activities: } \\
\text { monitoring of } \\
\text { higher competence } \\
\text { individuals/ groups; } \\
\text { Interaction } \\
\text { activities: } \\
\text { cooperation }\end{array}$ & $\begin{array}{l}\text { Diverse } \\
\text { communal } \\
\text { (institutional) } \\
\text { environment }\end{array}$ & $\begin{array}{l}\text { Interpersonal } \\
\text { interactions } \\
\text { with higher } \\
\text { competence } \\
\text { individuals }\end{array}$ & $\begin{array}{l}\text { Acquired } \\
\text { competences; New } \\
\text { knowledge } \\
\text { creation/generatio } \\
\text { n }\end{array}$ \\
\hline \begin{tabular}{|l|} 
Incidental/ \\
accidental \\
learning \\
(Schugurensky, \\
2000; Marsick \\
and Watkins, \\
2001; Marsick et \\
al., 2006)
\end{tabular} & $\begin{array}{l}\text { Conscious - } \\
\text { through other } \\
\text { activities; } \\
\text { Unintentional; } \\
\text { Unstructured }\end{array}$ & $\begin{array}{l}\text { Diverse unplanned } \\
\text { activities; Action } \\
\text { activities: task } \\
\text { implementation, } \\
\text { experimentation; } \\
\text { Cognitive activities: } \\
\text { sense of organisa- } \\
\text { tional culture, } \\
\text { mistake awareness, } \\
\text { reflection; } \\
\text { Interaction } \\
\text { activities: } \\
\text { conversations, } \\
\text { cooperation }\end{array}$ & $\begin{array}{l}\text { Diverse, } \\
\text { unanticipated } \\
\text { by learner } \\
\text { environment: } \\
\text { daily } \\
\text { environment, } \\
\text { work } \\
\text { environment, } \\
\text { in and } \\
\text { outside } \\
\text { various } \\
\text { institutions }\end{array}$ & $\begin{array}{l}\text { Individual } \\
\text { learning; } \\
\text { Interpersonal } \\
\text { interactions }\end{array}$ & $\begin{array}{l}\text { Acquired new } \\
\text { knowledge, skills; } \\
\text { Competence } \\
\text { development; } \\
\text { Self-awareness of } \\
\text { learning } \\
\text { something } \\
\text { unintentionally; } \\
\text { Personal } \\
\text { development: self- } \\
\text { knowledge, } \\
\text { appearance of } \\
\text { consciousness }\end{array}$ \\
\hline
\end{tabular}


Ramune Bagdonaite-Stelmokiene, Vilma Zydziunaite. Considerations on Informal Learning: Different Concepts and their Dimensions

\begin{tabular}{|c|c|c|c|c|c|}
\hline $\begin{array}{l}\text { Experiential } \\
\text { learning } \\
\text { (Kolb, 1984; } \\
\text { Kolb \& Kolb, } \\
\text { 2008) }\end{array}$ & $\begin{array}{l}\text { Conscious; } \\
\text { Generally } \\
\text { unintentional; } \\
\text { Generally } \\
\text { unstructured }\end{array}$ & $\begin{array}{l}\text { Action activities: } \\
\text { diverse experience; } \\
\text { Cognitive activities: } \\
\text { investigation, } \\
\text { reflection, } \\
\text { formulation of new } \\
\text { concepts; } \\
\text { Interaction } \\
\text { activities: diverse } \\
\text { experience of } \\
\text { interpersonal } \\
\text { experience } \\
\end{array}$ & $\begin{array}{l}\text { Diverse, } \\
\text { generally } \\
\text { unanticipated } \\
\text { by learner } \\
\text { environment }\end{array}$ & $\begin{array}{l}\text { Individual } \\
\text { learning } \\
\text { Interpersonal } \\
\text { interactions }\end{array}$ & $\begin{array}{l}\text { Acquisition of } \\
\text { new experience } \\
\text { conceptions/ } \\
\text { constructions }\end{array}$ \\
\hline $\begin{array}{l}\text { Learning } \\
\text { through } \\
\text { socialization/ } \\
\text { tacit learning } \\
\text { (Schugurensky, } \\
2000 \text { ) }\end{array}$ & $\begin{array}{l}\text { Unconscious; } \\
\text { Unintentional; } \\
\text { Unstructured }\end{array}$ & $\begin{array}{l}\text { Daily activities: } \\
\text { action, cognitive, } \\
\text { interaction } \\
\text { activities }\end{array}$ & \begin{tabular}{|l|} 
Diverse, \\
unanticipated \\
by learner \\
environment: \\
daily \\
environment, \\
work \\
environment, \\
various \\
institutions
\end{tabular} & $\begin{array}{l}\text { Diverse } \\
\text { interpersonal } \\
\text { interactions }\end{array}$ & $\begin{array}{l}\text { Internationaliza- } \\
\text { tion and change of } \\
\text { values, views, } \\
\text { behaviour, skills; } \\
\text { Unintentional } \\
\text { learning }\end{array}$ \\
\hline
\end{tabular}

\section{Process}

Learning process covers the particular characteristics that are specific for each informal learning type, namely consciousness, intentionality and the structure. Characteristic of consciousness is significant for informal learning as individual should consider, anticipate, plan and reflect on the own learning process. The consciousness is expressed in self-directed learning (Livingstone, 2001; Lin \& Lee, 2014), self-regulated learning (Jossberger, 2010; Morgan, 2013), self-managed learning (Cunningham, 2010; McConnell, 2013), as well as in situated learning (Lave \& Wenger, 1991; Chaiklin \& Lave, 1993) types. However, other authors refer to opposing concept of unconsciousness linking it to socialization. Schugurensky (2000) views learning through socialization in the context of daily life, thus not knowing that they learn something while everything flows unconsciously. Consciousness appears when learner views own experience in retrospect and perceives that s/he acquired something through accomplished activities. However, learner should reflect the acquired learning experience consciously and create new experience concepts in order to test them in new situations, as characterized by experiential learning (Kolb \& Kolb, 2008).

Intentionality is another characteristic of informal learning being related to predefined intention of learning (Schugurensky, 2000). Though some authors (Marsick \& Watkins, 2001; Marsick et al., 2006) emphasize that informal learning may be distinguished by reverse characteristic, namely unintentionality. 
Individual does not set the goal in advance with the aim to acquire knowledge and skills. The developed competences as the result of participation in both unforeseen and indirect activities are observed after particular experiential process is over. This is characteristic for both incidental / accidental learning and learning through socialization when individual does not foresee intentional learning and may not even know that s/he learnt something. Therefore, the latter learning type is also called tacit knowledge (Schugurensky, 2000). Kolb \& Kolb (2008) referring to experiential learning indicate similarly that individual may not anticipate own learning goals. However, it is supposed that this informal learning type may cover the aspect of intentionality when the individual intentionally tests and applies new constructed concepts of experience in the new situations.

The structure belongs to another characteristic of informal learning. It is related to conscious and intentional anticipatory planning of future learning activities, namely how and what will be learnt. This characteristic is proper to self-directed learning, self-managed learning, self-regulated learning, and situated learning. Learner oneself considers to be the manager of learning process (Schugurensky, 2000). Here learner's autonomy is disclosed (McConnell, 2013). Following this incidental / accidental learning (Schugurensky, 2000) is distinguished as learner does not anticipate learning process in advance or tacit learning / socialization (Schugurensky, 2000), experiential learning (Kolb \& Kolb, 2008) that may occur on a daily basis.

\section{Activity}

The informal learning is characterized by the following activities: action activities, cognitive activities and interaction activities. All of them overlap each other. Despite the fact that all the types of informal learning possess those activity groups, the content provided is different.

Action activities may refer to learning by doing, diverse professional and social practices, implementation of various tasks, experimentations, and daily actions. Daily actions are common to every informal learning type. Though Schugurensky (2000) mention both experiential learning and tacit learning / socialization being implemented through various casual activities that are not anticipated and planned in advance. Meanwhile, the authors describing selfdirected learning (Livingstone, 2001; Lin \& Lee, 2014), self-regulated learning (Zimmerman, 1990; Jossberger, 2010; Morgan, 2013) and self-managed learning (Cunningham, 2010; McConnell, 2013) emphasize conscious anticipation of individual to set learning activities. Lave \& Wenger (1991), Chaiklin \& Lave (1993) describe situated learning and highlight social practice as one more activity of informal learning. The aspect of social practice is 
Ramune Bagdonaite-Stelmokiene, Vilma Zydziunaite. Considerations on Informal Learning: Different Concepts and their Dimensions

characteristic for this type, namely all the activities - action activities, cognitive activities and interaction activities - occur in particular social practices.

The cognitive activities of informal learning cover the learner's reflection, self-control, motivation, monitoring, researching, learning from mistakes and construction of new experience conceptions. The reflection and introspection are highlighted in definitions of self-directed learning, self-regulated learning and self-managed learning (Garrison, 1997; Livingstone, 2001). Those definitions are united by the common characteristic - learner's self-management and selfcontrol mechanism. Thus, referring to self-directed learning, self-regulated learning and self-managed learning the autonomy and initiative of a learner is emphasized, as well as his / her ability to choose learning activities consciously (Pintrich \& Zusho, 2002; Loyens et al., 2008). Learner plans and pilots the learning on his / her own, treating it as condition for lifelong self-development. The motivation of learner is also important as a basis of what, how, and which activities are needed to learn (Garrison, 1997). Learning activities might not be planned in advance. Then the individual lacks self-management and control mechanism. This is common for incidental / accidental learning (Schugurensky, 2000). However, the reflection of accomplished activities and diverse situation is also very important in order to perceive the acquired value.

The individual learns through diverse social interactions. Still, the accomplishment of activities might be anticipated by learner in advance (characteristic for self-directed learning, self-regulated learning, self-managed learning and situated learning) or unanticipated, namely individual has learnt something unintentionally and unplanned during diverse social interactions. This is characteristic for incidental learning (Marsick \& Watkins, 2001; Marsick et al., 2006) when individual learns something accidentally by communicating with other people; and experiential learning or learning through socialization (Schugurensky, 2000) when individual learns something through diverse interpersonal experience.

\section{Context}

Informal learning might occur in any context. Learning contexts might be anticipated and planned or, on the contrary, unanticipated and unplanned by learner (Pintrich \& Zusho, 2002; Cunningham, 2010). Learner might anticipate learning context on his / her own, and such conscious aspect of planning the place might be contributed to self-directed learning, self-regulated learning, self-managed learning, and situated learning (Livingstone, 2001). Those contexts might be very diverse and sometimes it is difficult to name them as they are shifted from each other. However, analysing situated learning Lave \& Wenger (1991), Chaiklin \& Lave (1993) define the learning context by focusing on the community or institutional environment. However, it might be discussed 
regarding the type of informal learning occurrence on a daily basis. Referring to this approach, situated learning overlaps with the learning through socialization, when learning may occur in both conscious and planned, and unconscious and unplanned contexts.

Learning context might be unanticipated by the individual and this is characteristic for incidental / accidental learning or learning through socialization (Marsick \& Watkins, 2001; Marsick et al., 2006). Kolb \& Kolb (2008) discuss about experiential learning stating that such learning usually occurs in unanticipated environment. Anyway, when the learner experiences something and due to the reflection creates new concepts of experience, the application of experience causes the anticipated learning context.

\section{Interactions}

Informal learning might occur both individually and through interpersonal interactions. Individual informal learning indicates that learner plans and anticipates learning goals on his / her own, then self-regulation and self-control appears while learner evaluates him/herself referring to the different aspects of learning (Zimmerman, 1990). Such characteristics of individual learning are common for self-regulated learning (Loyens et al., 2008; Jossberger, 2010) or self-managed learning (Cunningham, 2010; McConnell, 2013).

Interpersonal interactions are important in informal learning. Those interactions might appear in daily environment, namely family, working place, community, society. Lave \& Wenger (1991), Chaiklin \& Lave (1993), Marsick (2009) indicate that the situated learning is experienced through interpersonal interactions, because knowledge is created when individual participates in a group, community or working environment of higher competence. Significance of interpersonal interaction is perceived in learning through socialization, as internationalization and change of values, attitudes, behaviour, and skills occur in daily interpersonal interactions (Schugurensky, 2000).

Both the individual learning and learning through interpersonal interactions might be chosen consciously. A learner may study individually, then learning may be organized on the basis of personal reflection or communicating with other persons - these are characteristics of self-directed learning (Duguit \& Schugurensky, 2013). Incidental / accidental or experiential learning occurs both individually or through interpersonal interactions, though these interactions are not anticipated consciously or planned by a learner him/herself (Callaghan, 1999; Kolb \& Kolb, 2008). Thus, different concepts of informal learning may reveal the aspects of both individual and interpersonal interactions, which overlap and therefore are complicated to distinguish. 
Ramune Bagdonaite-Stelmokiene, Vilma Zydziunaite. Considerations on Informal Learning: Different Concepts and their Dimensions

\section{Outcomes}

Learning outcomes might be anticipated and planned in advance (characteristics of self-directed, self-regulated, and self-managed learning). Learner knows exactly the lacking aspects or things important to learn and discover once again (Gibbons, 2002; Lin \& Lee, 2004; Cunningham, 2010). Anticipated specific knowledge and skills are requested for solving the problems of real world. Lave \& Wenger (1991), Chaiklin \& Lave (1993) indicate creation and generation of knowledge rather than obtaining of new knowledge and this is specific for situated learning type.

Learning outcomes might be even not planned or anticipated, namely a learner only later realizes that something is learned, acquired some skills and competencies. Due to reflection and communication the individual perceives what was learnt and which learning outcome has been achieved. This is specific characteristic of incidental / accidental learning (Schugurensky, 2000). Learning through socialization highlights the change and internationalization of values, attitudes, behaviour, skills referring to unconscious learning. Learner cannot describe when, where, how and with whom s/he acquired the knowledge, skills, personal development, embedded values and attitudes. All types of informal learning are characterized by the common outcome - personal development of a learner. Informal learning outcomes might be distinguished to supplemented and transformative. Supplemented outcomes complement learner's store of knowledge improving certain skills, developing particular values and enhancing or strengthening existing knowledge, values and attitudes. This means the continuous learning. Transformative outcomes acquired during informal learning challenge a learner to change radically the existing initial knowledge, values and attitudes. Both supplemented and transformative learning outcomes are characteristics for all types of informal learning.

\section{Discussion}

Characteristics of informal learning process - consciousness, intentionality and structure setting - are specific for all informal learning types, therefore various overlaps are observed while applying them. The consciousness covers not only anticipated, measured, planned learning, but the personal reflection on acquired learning experience as well. In this case of learning through socialization cannot be assumed as entirely unconscious learning, which is prescribed for informal learning type. Referring to the intentionality this learning type represents unanticipated, unplanned and therefore unstructured learning (Schugurensky, 2000). Distinction of intentionality and structure allows to recognise diverse informal learning types (Marsick \& Watkins, 2001; Marsick et al., 2006). Yet, strict distinction of experiential learning and 
incidental / accidental learning has no reason as both informal learning types allow the individual to perceive that s/he has learnt something referring to the particular indirect or accidental experiences, activities or situations.

Activities overlap in all the informal learning types therefore it is difficult to determine in which type of informal learning it is dominating. The same activities may serve as a basis for incidental / accidental learning, experiential learning or learning through socialization (Jossberger, 2010; McConnell, 2013; Morgan, 2013; Lin \& Lee, 2014). The informal learning lacks the personal selfmanagement and control, and learner does not accept the occurring activities as learning (Schugurensky, 2000). The scientists provide different views arguing if informal learning covers implicit (implied, latent) or incidental (accidental, indirect) activities. The authors of this article presume that if a learner reflects on learning experience acquired through other indirect and not anticipated activities, this refers to informal learning. Here the outcome - consciously realized new experience, acquired knowledge and skills. Though individual is not able to tell how and when s/he has learnt particular things, and the learning outcomes and personal development are always noticed and considered.

Context of informal learning is described with differently, as it may appear at working place, family, while browsing internet, reading books or reflecting on acquired experience. Even if individual anticipates and plans learning context for self-directed learning, self-regulated learning, self-managed learning, situated learning (Livingstone, 2001), the same context may serve as a platform for other types' informal learning. It is difficult to identify the content of context as informal learning dimension in each informal learning type, because the different learning contexts overlap and extend each other.

Identifying interactions it is recognized that informal learning might occur individually or by interacting. Though Pintrich \& Zusho (2002), Loyens et al., (2008) McConnell (2013) emphasize the individual learning while discussing about self-regulated learning and self-managed learning. However the authors of present article presume that learning types being mentioned might occur by experiencing various social interactions. Though importance of interactions is emphasized in learning through socialization (Schugurensky, 2000) or situated learning (Marsick, 2009), yet individual has to reflect diverse social experience personally in order to perceive the own learning outcomes.

During informal learning it is difficult or almost impossible to set learning outcomes precisely as informal learning is affected by many factors. Gibbons (2002), Lin \& Lee (2004), Cunningham (2010) talking about self-directed, selfregulated, and self-managed learning emphasize the learner's intentions to anticipate learning outcomes in advance. However after some time it might be observed that even unplanned or unanticipated knowledge was obtained. 
Ramune Bagdonaite-Stelmokiene, Vilma Zydziunaite. Considerations on Informal Learning: Different Concepts and their Dimensions

\section{Conclusions}

Informal learning concept is ambiguous and thus distinguished by the diverse interpretations. This is a broad concept incorporating diverse learning processes, activities, contexts, interactions and outcomes. It is difficult to present definitions of homogeneous informal learning being influenced by the diverse attitudes and historical contexts as this concept, as well as overlaps and detachments of definitions of diverse informal learning types are changing.

Informal learning occurs in every life and learning situation referring to educational institutions, working environment, family, leisure time. It has been influenced as well by the fact that the particular learning part occurs unconsciously when the learner does not recognize particular competences to be achieved. Informal learning might be unanticipated, self-managed, intentional and planned. It covers both individual processes (informal learning at home, working environment) and social processes (informal learning in communities or contexts of social activities).

However, informal learning might be considered as continuum between self-directed learning, self-regulated learning, self-managed learning, experiential learning, incidental/accidental learning, situated learning, learning through socialization / tacit learning. The diverse types of informal learning supplement each other rather than compete against. Learning intentionality and process or context setting might reveal at distinct degrees, yet informal learning is considered to be the construct that covers supplementary learning forms, activities and outcomes.

\section{References}

Carliner, S. (2013). How Have Concepts of Informal Learning Developed Over Time? Performance Improvement, 52 (3), 5-11.

Chaiklin, S., \& Lave, J. (1993). Understanding practice. Perspectives on Activity and Context. UK: Cambridge University Press.

Cunningham, I. (2010). Learning to Lead - Self-Managed Learning and How Academics Resist Understanding the Processes. Development and Learning in Organizations: An International Journal, 24 (2), 4-6.

Gola, G. (2009). Informal Learning of Social Workers: A Method of Narrative Inquiry. Journal of Workplace Learning, 21 (4), 334-346.

Golding, B., Brown, M., \& Foley, A. (2009). Informal Learning: a Discussion Around Defining and Researching its Breadth and Importance. Australian Journal of Adult Learning, 49 (1), 35-56.

Jossberger, H., Brand-Gruwel, S., Boshuizen, H., \& Van de Weil, M. (2010). The Challenge of Self-Directed and Self-Regulated Learning in Vocational Education: A Theoretical Analysis and Synthesis of Requirements. Journal of Vocational Education and Training, 62 (4), 415-440. 
Kolb, A. Y., \& Kolb, D. A. (2008). Experiential Learning Theory: A Dynamic, Holistic Approach to Management Learning, Education and Development. In: Armstrong, S. J., Fukami, C. (Eds.) Handbook of Management Learning, Education and Development. London: Sage Publications.

Kolb, D. A. (1984). Experiential Learning. Englewood Cliffs, NJ: Prentice-Hall.

Lave, J., \& Wenger, E. (1991). Situated Learning. Legitimate Peripheral Participation. UK: Cambridge University Press.

Lin, Y. M., \& Lee, P. Ch. (2014). Informal Learning: Theory and Applied. International Journal of Business and Commerce, 3 (5), 127-134.

Livingstone, D. W. (2002). Mapping the Iceberg. NALL Working Paper, 54.

Livingstone, D. W., \& Sawchuk, P. H. (2005). Hidden Knowledge: Working-Class Capacity in the „Knowledge Based Economy“. Studies in the Education of Adults, 37 (2), 110123.

Loyens, S. M. M., Magda, J., \& Rikers, R. M. J. P. (2008). Self-Directed Learning in Problem-Based Learning and Its Relationships with Self-Regulated Learning. Educational Psychology Review, 20, 411-427.

Marsick, V. J. (2009). Toward a Unifying Framework to Support Informal Learning Theory, Research and Practice. Journal of Workplace Learning, 21 (4), 265-275.

Marsick, V. J., \& Watkins, K. E. (2001). Informal and Incidental Learning. New Directions for Adult and Continuing Education, 89, 25-34.

Marsick, V. J., Watkins, K. E., Callahan, M. W., \& Volpe, M. (2006). Reviewing Theory and Research on Informal and Incidental Learning. Available at: http://files.eric.ed.gov/fulltext/ED492754.pdf. Accessed on 23 September 2015.

McConnell, I. M. (2013). “You Never Stop Learning”: Informal and Incidental Workplace Learning and Women City Managers' Career Development. Dissertation of Philosophy, Georgia: University of Georgia.

Morgan, S. E. (2013). Self-Regulation and Cultural Orientation on the Academic Achievement of University Students on Distance Education I Kampala, Uganda. Global Journal of Interdisciplinary Social Sciences, 2 (4), 1-8.

Pintrich, P. R., \& Zusho, A. (2002). Student Motivation and Self-Regulated learning in the College Classroom. In Smart, J. C., Tierney, W. G. (Eds.) Higher Education: Handbook of Theory and Research. New York: Agathon Press.

Schugurensky, D. (2000). The Forms of Informal Learning: Towards a Conceptualization of the Field. WALL Working Paper, 19.

Straka, G. A. (2004). Informal Learning: Genealogy, Concepts, Antagonism and Questions. Bremen: University of Bremen.

Tough, A. (2002). The Iceberg of Informal Adult Learning. NALL Working Paper \# 49 2002. Available at: http://nall.oise.utoronto.ca/res/49AllenTough.pdf Accessed on 28 September 2015.

Zimmerman, B. J. (1990). Self-Regulated Learning and Academic Achievement: An Overview. Educational Psychologist, 25 (1), 3-17. 